DOI: $10.2478 /$ rpp-2018-0025

PhD in Pedagogy, Lecturer, TETIANA TRON

Kyiv National Linguistic University, Ukraine

Address: 73 Velyka Vasylkivska St., Kyiv, 03150, Ukraine

E-mail: t.tron@ukr.net

\title{
SPECIFICS OF FUTURE BORDER PROTECTION SPECIALISTS' TRAINING IN THE USA AND UKRAINE: COMPARATIVE ANALYSIS
}

\begin{abstract}
Nowadays the issue of border protection is vitally important for national security of every country to guarantee protection of citizens. In this regard, it is important to study positive experience of world practices in this field. The current article deals with the comparative analysis of the system of border protection specialists' training in the United States and Ukraine. The article focuses on specifying learning methods, forms of border protection specialists' training. Moreover, the issue of border protection specialists' training within the framework of pedagogical theory and practice has been presented; main stages of development of the USA and Ukrainian border protection training system have been processed and presented; professional requirements of American and Ukrainian border protection specialists have been described and compared. Additionally, curriculum standards of physical, firearm, law, operational and communicative aspects of professional training in the field of border protection in the USA and Ukraine have been mentioned. Furthermore, the research investigates principles and specifics of future border protection specialist' professional training with detailed description of the educational process in the USA and Ukraine. Great attention has also been paid to the specific forms, methods and strategies of professional border protection training. The comparative analysis of American and Ukrainian professional training system in the field of border protection has been conducted. Basing on criteria of different training aspects, the conducted analysis enables to state new possibilities of progressive American ideas in the field of border protection issues to be implemented into the practice of Ukrainian future border protection specialists' training.

Keywords: border protection, professional training, future border protection specialists, comparative analysis, training center, learning methods, the USA Border Patrol, the State Border Guard Service of Ukraine.

\section{INTRODUCTION}

At present moment national protection plays a very important role not only in a political, but also in a social and cultural life of every country in the world. To guarantee border protection means to guarantee safety and security. High security level demands high-quality border protection specialists' training. It has been determined that nowadays owing to the fact, that the border protection guarantees the protection of social-political life of any state, the issues of professional training of border specialists in the countries of the Euro-Atlantic area are solved on the governmental level and needs news ideas for modern solutions.

Being a country with a long, successful law-enforcement reorganization experience and future Border patrol specialists' training in particular, the USA can have elements of positive ideas for Ukrainian future border patrol specialists' training.
\end{abstract}


Sciendo Порівняльна професійна педагогіка 8(2)/2018

Comparative Professional Pedagogy 8(2)/2018

\section{THE AIM OF THE STUDY}

The aim of our research is to process the system, forms, easy and methods of future border protection specialist' training; to highlight the specifics of professional training in contrasted countries; to present the results of the comparative analysis of the USA and Ukrainian future border protection specialists' training; to state out elements of positive USA experience in the field of border protection.

\section{THEORETICAL FRAMEWORK AND RESEARCH METHODS}

The issue of foreign border protection in the system of law-enforcement bodies and future border protection specialists' training as its main aspects has drawn attention by a great number of Ukrainian scholars. Theoretical and methodological concepts of our research are based on scientific works by such scholars as: A. Balendr (2016) (Hungary); O. Kireiev (2011), N. Ryndenko (2014), (Polish experience); I. Bloshchynskyi (2015) (the USA experience); V. Prymak (2013) (the EU countries), O. Danylenko (2015) (the NATO countries). The problem risen in our research has also been investigated by a great number of American and European scholars: K. Hernandez (2010) (the US Border Patrol historical facts); R. Chilcoat (1999) (military education); J. Glennon (2010) ( law enforcement bodies research); K. Larson (2016) (national protection).

To reach the aim of the current article the following methods have been used: theoretical analysis, synthesis, systematization, generalization and the method of comparative analysis.

\section{RESULTS}

The results of the analysis of scientific literature and sources have shown that American law-enforcement system has its own unique structure and organization (Carter, 1999). Some elements of the U.S. law-enforcement bodies are included into the system of the Homeland Security, which consist of a great variety of services, agencies and departments. The U.S. Customs and Border Protection is one of those agencies. In its turn, it includes the U.S. Border Patrol Agency. Training of future specialists in this field includes the following stages: basic Border Patrol Academy training, post-academy training, field operations training, advanced training (The USA Customs and Border Protection, 2017). As the conducted research shows, the choice of forms and methods of the U.S. Border Patrol specialists' professional training is based on the ideas of practical implementation of acquired skills and abilities. Thus, it was stated that the personal oriented approach dominated in the practice of the U.S. Border Patrol specialists' professional training. The practical classes are called "imitating classes" as they imitate real life situations on the border. Thus, future specialists "work out" possible true to life situations that they can face on duty. Special actors, imitating the illegal migrants, smugglers are often invited to take part in a role-play classes. However, the future border protection specialists have a limited theoretical course on the law disciplines in the form of short lectures.

The research proves that different aspects of the U.S. border protection specialists have different methods and forms of its implementation. Thus, the most efficient form of law aspect of professional training course is the combination of theoretical (for learning of theoretical issues) and practical (role-plays) classes; physical training presupposes having a great amount of practical physical exercises and workouts (hand-to-hand fighting, physical activity and agility classes); communicative training (the Spanish language) deals with the task-based learning, role-plays, immersion courses; firearms training includes short lectures (narration), explanation, exposing, individual work and practice with the instructor; driving training contains the elements of a lecture (for theoretical explanation) and practical lessons 
with the instructor, and then individual driving. Among the specifics of the American Border Patrol specialists professional training the following can be noted: each candidate has to undergo the preliminary physical training course; the training process for all lawenforcement bodies is conducted in federal training center; a great attention is paid to the Spanish language learning for its practical usage on the ports of entry; the mentor system for future Border Patrol specislists is on a high level. It means that every entry level specialist has a mentor, who helps them in the process of practical work. The mentor programme is a federally subsidized one, thus the mentors are financially motivated. Moreover, a future Border Patrol specialist has favorable study conditions: different special equipment, simulating machines, specially equipped shooting galleries.

At the same time may some researchers investigate Ukrainian future border protection specialists' training (Halimov, 2003; Didenko, 2009; Ishchenko \& Filipov, 2002). As the research shows the Ukrainian system of future border protection specialists' undergoes the requirements of Ministry of Education and Science of Ukraine and has nation curriculum standards. As a matter of fact various aspects of professional training in this field have different methods and forms of its implementation. One of the efficient methods of Ukrainian professional training system in the field of border protection is combination of practical and theoretical parts.

To conduct the comparative analysis of specifics of future border protection specialists' professional training in the USA and Ukraine we took the system of basic training in both countries. Basic training of border protection specialists in the USA is provided in the Academy of Border Patrol within the general of the Federal LawEnforcement Training Center activity (further The USA training center). In Ukraine the basic training of younger personnel is provided in the Main Training Center of personnel training of the State Border Guard Service of Ukraine after Major General Ihor Momot (further Ukraining training center). While conducting the analysis the following criteria were taken into account: objective, law, diagnostic, technological and content.

So, in accordance with the objective criterion of the comparative analysis, it was stated out that that activity of the Ukrainian training center deals with complete professional training of younger personnel for the State Border Guard Service of Ukraine. In this regard, the aim of this professional training is to provide an educational degree certified by the Ministry of Education and Science of Ukraine. By this it is meant, that the system of professional training of future border protection specialists undergo the state educational standards. Controversially, the USA training center is aimed at basic training of future border patrol specialists in the system of all law-enforcement bodies' professional training that does not undergo national educational standards. Hence, the system of professional training of specialists in the field of the border protection in the USA undergoes federal bodies' standards and does not deal with educational establishments.

The law criterion of the comparative analysis shows that the two countries implement different systems of legal documents to provide the activity of their training centers in the field of border protection. Hence, the USA training center undergoes legal matters of the field acts and laws (Federal Law Enforcement Training Centers Strategic Plan, 2016). Meanwhile, the Ukrainian training center activity undergoes the legal issues and acts of national educational law papers (Pro profesiino-tekhnichnu osvitu, 1998).

The diagnostic criterion of the analysis was used in order to identify the system of final assessment in the contrasted countries. Thus, in the USA training center the final 
sciendo Порівняльна професійна педагогіка 8(2)/2018

Comparative Professional Pedagogy 8(2)/2018

assessment of future border patrol specialists' finishes with a complex of final computerbased testing only (using of IT technologies prevents from human factor risk in the process of assessment). During final assessment various imitators and simulators are used. In contrast, the Ukrainian training center finishes the training with classical written and oral testing.

The technological criterion of the comparative analysis deals with contrasting of forms and methods of professional training. Thus, it was found out that main forms of the USA training center are as follows: lecture (interactive, lecture-visualization, binary lecture); practical classes and workshops; role plays classes; seminars (instructions); trainings. As the research proves, role play method is one of the most efficient ones. In its turn, it can be explained by the fact that when future border protection specialists undergo the practical training in the form of role-play, they acquire necessary skills requires for a productive and successful work of a border protection specialist. Speaking about the methods, the following must be admitted: lecture, instruction, practical classes, demonstration and Taskbased learning (for the Spanish language). Both forms and methods of the USA system of future border protection specialists presuppose interchange with theoretical and practical background. Thus, they combine all necessary aspects of successful training.

At the same time, the Ukrainian system of future border protection specialists' presupposes including such forms as: tactical, battle drills exercises, practical classes, and tactical trainings with weapons, operations. Within the methods of training the following must be mentioned: explanations, instruction, lecture, individual work, demonstration, practical tasks. In the system of Ukrainian professional training in the field of border protection much attention is paid to theoretical background.

Finally, the content criterion of the comparative analysis deals with disciplines, duration of professional training and basic requirements for applicants. Thus, the curriculum of the USA training center is focused on the range of professional subjects learning (Personal Security, Law, Firearm, Driving, Disaster medicine, Fitness training, Operations, the Spanish language). The term of basic professional training is 55 days. Basic requirements for applicants are as follows: full medical examination, citizenship of the US, the age before 40 , the Polygraph test, the CBP entrance exam passing, physical fitness testing, federal criminal background check.

At the same time, in Ukraine the duration of basic training is 4,5 months. The curriculum is concentrated on the range of professional subjects (Tactics of the Border Service, Border Control, Administrative Management, Personal Security, Business Communication basics, Foreign Language, Ecological Security, Psychological Management etc.); the range of military subjects (the Ukrainian Armed Forces regulations, Line Training, General Tactics, Topography, Tactical Medicine); the range of comprehensive subject (Law, Economics, Physical Education, General Traffic rules). Main requirements for applicants are as follows: the citizenship of Ukraine, age before 37, and the range of entrance exams (English, physical fitness test), full medical examination.

All in all, the comparative analysis being conducted, the following recommendations can be put into Ukrainian practice of future border protection specialists' training: to unify the standards of firearm, physical, tactical, communicative standards of professional training for all Ukrainian law-enforcement bodies, to the create united Training Center with equal standards of professional training, to introduce tough system of entrance requirements, to implement the usage of various technologies into the integrated system of professional training, to implement role-play trainings into the system of professional training, to 
introduce the progressive ideas of the USA experience in communicative training of future border protection specialists.

\section{CONCLUSIONS}

So, the comparative analysis of specifics of the U.S. Border Patrol specialists' and the State Border Guard Service specialists' professional training proved that both systems have their own similarities and differences at the same time. The subject of the comparative analysis was the range of following components: organization, standards and structure of professional training of Border Guard establishments, main issues of training curriculum; forms and methods of general training and its individual components. The analysis proved that the US Border Protection system is characterized by its integrity and meets the standards of all law-enforcement bodies' professional training, having equal standards and principles. As a result of conducted analysis, the following criteria were taken into account: objective criterion, law criterion, diagnostic criterion, technological and content criteria. As the research showed, the balanced combination of national traditions in the field of future border protection specialists' training with some ideas of positive US Border Patrol experience in the field will be beneficial for the State Border Guard Service of Ukraine.

Further research should present other aspects of training in the field. Other directions of training investigation, such as: advanced training specifics of law-enforcement bodies are recommended for further investigation within the framework of a complex US law-enforcement specialists' training system.

\section{REFERENCES}

1. Balendr, A. (2016). Suchasnyi dosvid pidhotovky ofitseriv Derzhprykordonsluzhby Ukrainy v mizhnarodnii pravookhoronnii akademii Uhorshchyny. Visnyk Natsionalnoi akademii Derzhavnoi prykordonnoi sluzhby Ukrainy. Seriia: Pedahohika, 5. Retrieved from http: // w.w.w.nbuv.gov.ua/UJRN/Vnadped_2016_5_3.

2. Bloshchynskyi, I. (2015). Peculiarities of U $\bar{S}$ border guard officers training at the federal law enforcement training center using online campus. Comparative Professional Pedagogy, 5 (4), 57-61.

3. Carter, D. (1990). The evolution of higher education in law enforcement: Preliminary findings from a national study. Journal of Criminal Justice Education, 1 (1), 59-85.

$22,59-63$

4. Chilcoat, R. (1999). The Revolution in Military Education. Joint Force Quarterly,

5. Danylenko, O. B. (2015). Osoblyvosti profesiinoi pidhotovky fakhivtsiv pravookhoronnykh orhaniv u navchalnykh zakladakh providnykh krain NATO. Visnyk Natsionalnoi akademii Derzhavnoi prykordonnoi sluzhby Ukrainy. Seriia: Pedahohika, 5. Retrieved from http://nbuv.gov.ua/UJRN/Vnadped_2015_5_6.

6. Didenko, O. V. (2009). Formuvannia profesiinoi tvorchosti v maibutnikh ofitseriv Derzhavnoi prykordonnoi sluzhby Ukrainy. Khmelnytskyi: Natsionalna akademiia DPSU.

7. Federal Law Enforcement Training Centers Strategic Plan (2016-2018). Retrieved from https://www.fletc.gov/strategic-plan-pdf.

8. Glennon, J. (2010). Arresting communication: essential interaction skills for law enforcement. Washigton DC: LifeLine Training.

9. Halimov, A. V. (2003). Pidhotovka maibutnikh ofitseriv-prykordonnykiv do vykhovnoi roboty z osobovym skladom yak spetsyfichna pedahohichna problema, Materialy koferentsii "Pidhotovka vchytelia v suchasnykh umovakh". Sloviansk: SDPU. 
10. Hernandez, K. L. (2010). Migra!: a history of the U.S. border patrol (American crossroads). Oakland, CA: University of California Press.

11. Ishchenko, D. V., \& Filipov, A. F. (2002). Osnovy viiskovoi pedahohiky. Khmelnytskyi: NAPVU.

12. Kireiev, O. M. (2011). Profesiina pidhotovka prykordonnykiv Yevropeiskoho Soiuzu (na prykladi Prykordonnoi varty Respubliky Polshcha). Visnyk Natsionalnoi akademii Derzhavnoi prykordonnoi sluzhby Ukrainy, 5. Retrieved from https://www.nbuv. gov.ua/e-journals/...5/11komvrp.pdf.

13. Larson, K. W. (2016). U. S. Border Patrol (Protecting Our People). Mankato, MN: Amicus High Interest.

14. Zakon Ukrainy "Pro profesiino-tekhnichnu osvitu" (1998). Vidomosti Verkhovnoi Rady Ukrainy (VVR), 32, 215.

15. Prymak, V. P. (2013). Osoblyvosti pidhotovky politseiskykh kadriv krain Yevrosoiuzu v druhii polovyni XX - pochatku XXI stolittia. Zbirnyk naukovykh prats Khmelnytskoho instytutu sotsialnykh tekhnolohii universytetu "Ukraina", 1 (7), 199-220.

16. Ryndenko, N. M. (2014). Suchasni napriamy rozvytku profesiinoi pidhotovky 100ersonal prykordonnykh vidomstv u krainakh Yevropeiskoho Soiuzu. Naukovyi visnyk Chernivetskoho universytetu. Pedahohika ta psykholohiia, 712, 151-159.

17. The USA Customs and Border Protection. (2017). The USA customs and border protection. Retrieved from https://www.cbp.gov/border-security/ports-entry. 